\title{
The Effect of Perceived Ease of Use on the Quality of Accounting Information Systems and its Impact on the Quality of Accounting Information
}

Kun Wiryanti ${ }^{*}$, Fardinal

Department of Accounting Universitas Mercu Buana

\begin{tabular}{ll}
\hline DOI: $10.36348 /$ sjbms.2020.v05i12.004 & | Received: 01.12.2020 | Accepted: 09.12.2020 | Published: 14.12.2020
\end{tabular}

*Corresponding author: Kun Wiryanti

\section{Abstract}

This research aims to examine The Effect of Perceived Ease of Use on the Quality of Accounting Information Systems and its Impact on the Quality of Accounting Information using the Technology Acceptance Model (TAM) approach. Population in this research are the staffs at the accounting department, procurement/purchasing department, project support units, and productions in one of the oils \&amp; gas companies in Jakarta. The samples are 60 respondents who operate the accounting systems and the Director and managerial level who use the accounting information. Data were collected using questionnaires that used the Likert scale. Distribution and collection of questionnaires were carried out in April 2020. The results of testing showed perceived ease of use affects the quality of information systems. However, the level of influence is also influenced by other factors outside the information system. Like standard operating procedures as internal company controls. Meanwhile, the accounting information quality is strongly influenced by the information system quality. The better the information system quality, the better the quality of the resulting accounting information system.

Keywords: Perceived Ease of Use, The Accounting Information System Quality, Accounting Information Quality.

Copyright () 2020 The Author(s): This is an open-access article distributed under the terms of the Creative Commons Attribution 4.0 International License (CC BY-NC 4.0) which permits unrestricted use, distribution, and reproduction in any medium for non-commercial use provided the original author and source are credited.

\section{INTRODUCTION}

An organization, both profit, and non-profit organizations will run well if it is supported by a reliable information system. Without the quality of information systems, there will be no quality of accounting information [2]. Azhar Susanto [2] also said the accounting information system consists of integrated hardware, software, Brainware, procedures, telecommunication networks, and databases.

Many accounting software companies dictate how their clients should run their business with the program characteristics they offer. Sometimes the characteristics of the program do not match with what the client need. Software program characteristics sometimes can limit the ease of use of the system program. And clients or users have difficulty using and understanding the functions contained in the program.
From these problems, an error can occur during the data entry process and make the information presented will be incorrect. Financial statements as the outcome do not present the actual accounting information. When the accounting system program runs properly and the users can easily use and understand its functions, the result of financial and other company activities reports include in the accounting program will be accurate.

The accounting information system of every company varies based on the business type and what the management need. The completeness of its features should be adapted to existing conditions and activities. Ease of use of information systems is also an important requirement to_-support the data processing process. Difficulties in using information systems will require a long time to master the information system and take up time. 
The accounting information system constraints experienced by PT. Pos Indonesia in the year 2012, the system was still partial and not integrated. It takes months to see the financial transaction data of all branches in Indonesia. The slow rate of data completeness makes accounting information provided not show the current time data period.

Still, in the same year, Hoesen, as Director of Company Assessment of the IDX, said that mostly the low quality of information systems in Indonesia was indicated by the presence of 29 companies listing on the Indonesia Stock Exchange (IDX) that happened late submitting financial reports in the second quarter of 2012. Delays in submitting financial reports also indicated incomplete financial reports.

Another phenomenon related to perceived ease of use is stated in research (Priyandari, Y. et al. [3]) 'Application of System Application Product in Data Processing (SAP) in PT. MAK's Material ManagementProcurement Module', (May 2016), pp. 427 -433. Users of the SAP program at PT. Mega Andalan Kalasan experience difficulties using the system because the system characteristics are too complex and rigid. The IT team finds errors in the data that make the accounting information incorrect. So that financial reports often experience revision that causes a delay.

This study uses the Technology Acceptance Model (TAM) as the basic framework of thought. Based on the description of the phenomenon above, the authors identify the formulation of causality problems between Perceptions of Ease of Use, Quality of Accounting Information Systems, and Quality of Accounting Information.

1) How big the influence of perceived ease of use of the Accounting Information System on the Quality of Accounting Information? 2) How big the influence of the Quality of Accounting Information Systems on accounting information quality? 3) How big influence of perceived ease of use on the accounting information systems on the accounting information quality?

This research was conducted to prove theories and hypotheses in previous studies on factors that affect the quality of the Accounting Information System using the Theory Technology Acceptance Model (TAM) framework with the relationship between research variables as follows: 1) The effect of perceived ease of use ) accounting information systems on the quality of accounting information systems. 2) The effect of perceived ease of use (ease of use) of accounting information systems on the accounting information quality. 3). Effect of the quality of accounting information systems on the quality of accounting information.
Research on the quality of information systems using the Technology Acceptance Model (TAM) approach has been widely carried out. Among them is research conducted by Fardinal [4] wherein this study the quality of accounting information is measured using theory. Technology Acceptance Model (TAM). TAM can explain the effect of the internal control system on the quality of accounting information. TAM allows us to check and predict whether the components of the internal control system have been implemented properly and adequately in the accounting information system.

Sonia et al., [5] in a study entitled The Perceived Usefulness of Financial Information for Decision Making in Portuguese Municipalities: The Importance of Internal Control discusses the level of perceived benefits of financial information in supporting decision making. The results show a high degree of perceived usefulness of financial information for corporate political decision making and financial decisions, especially financial information presented on an accrual basis.

Ronny Andesto and Azhar Susanto [6] discusses the organizational structure has a significant effect on the Quality Management Accounting Information System. The lack of quality management accounting information systems is caused by a lack of organizational structure. The quality of management accounting information systems can be improved by increasing the effectiveness of the organizational structure.

Based on the background described above, the authors intend to research the quality of accounting information systems with the Technology Acceptance Model (TAM) approach using different variables from previous studies entitled "The Effect of Perceptions of Ease of Use on the Quality of Accounting Information Systems and their Impact on Quality. Accounting Information "

\section{LITERATURE REVIEW Reason Action Theory (TRA)}

Theory of Reasoned Action (ToRA or TRA) aims to explain the relationship between attitudes and behavior in human action. It is mainly used to predict how individuals will behave based on pre-existing behavioral attitudes and intentions. Individual decisions to engage in certain behaviors are based on the results that the individual hopes will emerge as a result of performing these behaviors. Developed by Martin Fishbein and Icek Ajzen in 1967, this theory stems from previous research in social psychology, persuasion models, and attitude theory.

Fishbein and Ajzen in Jogianto [7] state that Reasoned Action Theory is based on social psychology, according to Reasoned Action Theory, individual performance of predetermined behavior will be 
determined by the intent of the action to be carried out with the aim of the behavior being jointly determined by individual attitudes and subjective norms.
The TRA construction developed by Fishbein and Ajzen [7] can be seen in Figure 1.1.

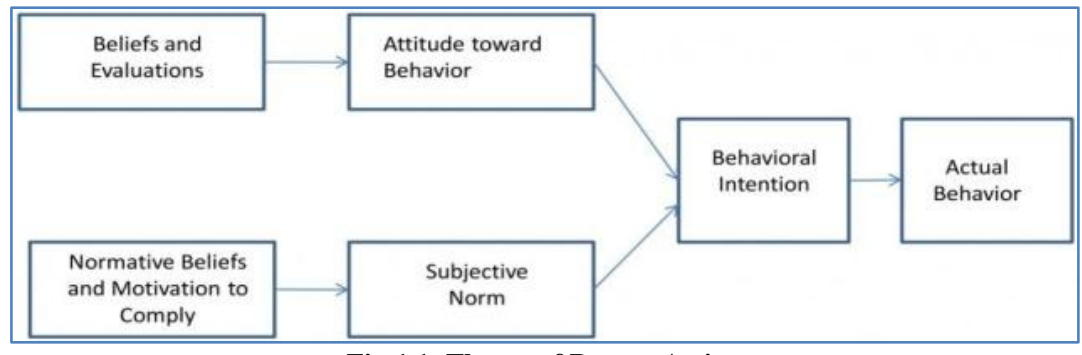

Fig-1.1: Theory of Reason Action

\section{Technology Acceptance Model}

The Technology Acceptance Model (TAM) introduced by Fred D. Davis is an information systems theory that models how users accept and use technology. TAM has continued to be studied and expanded - two major improvements are TAM 2 [8] and Integrated Theory of Technology Acceptance and Use (or UTAUT, Venkatesh, et al. [9]). TAM 3 has also been proposed in the context of e-commerce to include the effects of trust and perceived risk on system use [10]. Perceived usefulness and Perceived ease of use are two fundamental norms in TAM for predicting behavior.

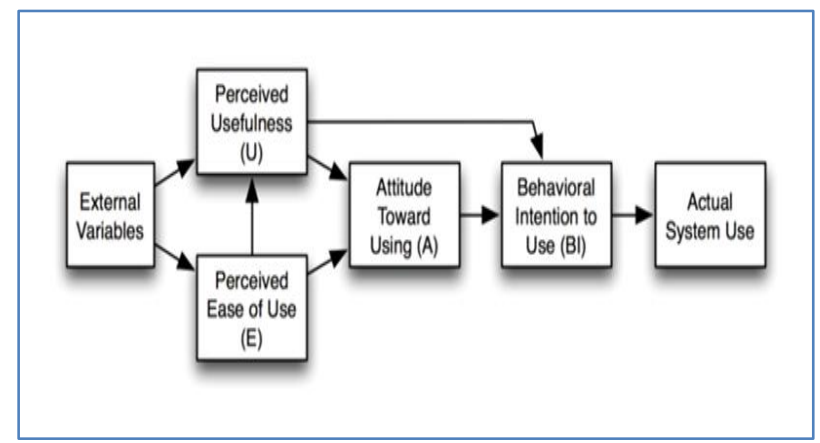

Fig-1.2: Technology Acceptance Model (TAM)

The main objective of TAM is to become a basic understanding of the influence of external factors on internal beliefs and behavior.

\section{Accounting Information System}

Accounting Information System is a system that collects, records, stores, and processes data to produce information for decision-makers [11]. Romney \& Steinbart [11] also mention, there are seven components of the Accounting Information System, namely:
a) Human.
b) Procedures and instructions.
c) Data.
d) Software.
e) Information technology infrastructure.
f) Internal control.
g) Safety measures.

These seven components enable the Accounting Information System to fulfill three important functions in business, namely;

a) Collect and store data about the organization's activities, resources, and personnel. Organizations have several business processes, such as making the sale or purchase of raw materials, that are repeatable.

b) Turning data into information so the management can plan, execute, control, and evaluate activities, resources, and personnel.

c) Provide adequate controls to protect the organization's assets and data.

The use of accounting information systems is used to (a) produce external reports, (b) support routine operating activities, (c) support information requirements for decision making, (d) support planning and control, and (e) provide internal control [12].

\section{Accounting Information System Quality}

Understanding the Quality of Accounting Information Systems according to Azhar Susanto [6] is "The quality of accounting information systems as a concept that must be integrated with all elements and sub-elements involved in forming an accounting information system to produce quality accounting information". According to Stair \& Reynolds [13], the quality of accounting information systems is (a) flexible, (b) efficient, accessible (c) accessible, and timely. Seddon [14] states that the success of information systems is conceptualized as a value 
judgment made by a person from a stakeholder's point of view. Also, Gelinas \& Wriggins [15] suggested that the effectiveness of an accounting information system is a measure of the success of an accounting information system meeting the objectives set.

Heidman [16]. Stated the dimensions of the quality of the accounting information system consists,(a) Integration, (b) Flexibility, (c) Accessibility, (d) Formalization, (e) Media Wealth. From two sources Heidman [16] and Stair \& Reynolds [17], researchers summarize and limit the dimensions of the quality of accounting information systems as follows; (a) Flexibility (b) Accessibility (c) Integration (d) Formalization.

\section{Accounting Information Quality}

The value of information is directly related to how it helps decision-makers achieve their organizational goals. Valuable information can help people and their organizations perform their tasks more efficiently and effectively [17]. Further, information is of high quality, information on products whose characteristics, attributes, or qualities help make it valuable to them [18].

The quality of accounting information can be explained in several dimensions. Hall [19] argues that the dimensions of information quality consist of: (a). relevance, (b). timeliness, (c). accuracy, (d). completeness, and (e). summary. Besides, Gelinas et al. [15] and McLeod [20] suggest that the dimensions of information quality are accurate, timely, relevant, and complete. Much earlier, Hicks [21] stated relevance, timeliness, accuracy, and verifiability as criteria for information quality.

Meanwhile, Maurice [22] and O'Briens \& Marakas [18] summarize the importance of information and classify it into three dimensions, namely: time (consisting of timeliness, currency, frequency, period); content (accuracy, relevance, completeness, conciseness, scope, performance); and form (clarity, detail, sequence, presentation, media) In this study, the dimensions of accounting information quality are: (a) Relevance (b) Accuracy (c) Verification.

\section{Hypothesis}

H1: Perceived Ease of Use affects the Quality of the Accounting Information system System-and also the Quality of Accounting Information.

$\mathrm{H} 2$ : The quality of information systems affects the quality of accounting information.

H3: Perceived Ease of Use affects the Quality of Accounting Information.

\section{RESEARCH METHODS}

This research is a type of causal research. Causal research aims to test hypotheses about the effect of one or more variables (independent variables) on other variables (dependent variable). The data in this study is in the form of a questionnaire included in quantitative research. This study uses primary data in the form of the respondent's answers from middle and upper-level managers and staff at the research site.

The population is the accounting, procurement/purchasing, project admin unit in each division, and production division unit at the Batam branch office. This includes the accounting department in the company's central unit. The total number of respondents was 60 users of accounting information systems consisting of staff, supervisors, and managers/head units of each functional division and the Director where the research was conducted as users of financial reports or accounting information. In this study, data collection was carried out using a Likert scale questionnaire technique. And the method of analysis in this research is the Structural Equation Model (SEM) using Partial Least Square Software (PLS), namely SmartPLS version 3.0. for measuring the level of validation and reliability of data and descriptive analysis.

\section{RESULTS}

Test Assumptions and Quality of Research Instruments.

Table Recapitulation of Reliability and Validity Constructs

\begin{tabular}{|c|c|c|c|c|}
\hline Variable Indicators & Cronbach's Alpha & rho_A & $\mathbf{C R}$ & AVE \\
\hline Perceived Ease of Use & 0.714 & 0.721 & 0.806 & 0.387 \\
\hline Individual interactions with the system are clear and easy to understand & 0.747 & 0.998 & 0.877 & 0.783 \\
\hline It doesn't take much effort to interact with the system & 0.597 & 0.597 & 0.832 & 0.713 \\
\hline The system is easy to use & 1.408 & 1.000 & 1.066 & 1.000 \\
\hline It is easy to operate the system according to what the individual wants to do & 0.758 & 0.793 & 0.891 & 0.803 \\
\hline Accounting Information System Quality & 0.809 & 0.823 & 0.858 & 0.435 \\
\hline Flexibility & 0.491 & 0.508 & 0.795 & 0.660 \\
\hline Accessibility & 0.449 & 0.473 & 0.781 & 0.642 \\
\hline Integration & 0.562 & 0.562 & 0.820 & 0.695 \\
\hline Formalization & 0.496 & 0.543 & 0.793 & 0.659 \\
\hline Accounting Information Quality & 0.764 & 0.790 & 0.843 & 0.524 \\
\hline Accuracy & 0.768 & 0.806 & 0.895 & 0.810 \\
\hline Relevance & 0.556 & 0.614 & 0.813 & 0.686 \\
\hline Verification & 1.000 & 1.000 & 1.000 & 1.000 \\
\hline
\end{tabular}


The reliability and validity construct table above shows each variable indicator has a Composite Reliability value $\geq$ of 0.8 , and several indicators show Cronbach's Alpha value is $\leq 0.7$, still acceptable because it refers to the Composite Reliability value. A book entitled A Primer on Partial Least Square Structural Equation Model, states: Cronbach's alpha is sensitive to the number of items in the scale and generally tends to underestimate the internal consistency reliability. As such, it may be used as a more conservative measure of internal consistency reliability. Due to Cronbach's alpha's limitations, it is technically more appropriate to apply a different measure of internal consistency reliability, refers to as composite reliability [23].

It can be concluded that the indicators of each variable are valid for measuring the construct. The AVE value for the PEOU and AISQ variables is below 0.5, but it considers sub marginal because the $\mathrm{CR}$ value is $\geq$ 0.8 . The AIQ variable has an AVE value $\geq$ of 0.5 has high discriminant validity.

\begin{tabular}{|c|c|}
\hline Independent Variable & VIF \\
\hline Perceived Ease of Use & 1.642 \\
\hline Accounting Information System Quality & 1.491 \\
\hline
\end{tabular}

Based on the results in the table above, shows that all independent variables (Perceived Ease of Use and Quality of Accounting Information Systems) produce VIF values that are less than 10. Thus it can be stated that the two models are declared to have no multicollinearity symptoms. The assumption of multicollinearity is fulfilled.
Table of Determination Coefficient Results

\begin{tabular}{|l|c|c|}
\hline \multicolumn{1}{|c|}{$\begin{array}{c}\text { Dependent } \\
\text { Variable }\end{array}$} & $\begin{array}{c}\text { R } \\
\text { Squared }\end{array}$ & $\begin{array}{c}\text { Adj. R } \\
\text { Squared }\end{array}$ \\
\hline $\begin{array}{l}\text { Accounting } \\
\text { Information } \\
\text { Quality }\end{array}$ & 0.135 & 0.120 \\
\hline
\end{tabular}

Based on the table above, shows that the coefficient of determination of the Quality of Accounting Information is 0.120 or $12 \%$. This means that the contribution of Perceptions of Ease of Use on the Quality of Accounting Information Systems to the Quality of Accounting Information is $12 \%$, the remaining $88 \%$ is the contribution of other variables not discussed in this study.

Multiple Regression Linear Equations

\begin{tabular}{|l|r|r|r|}
\hline & Coefficients & Standard Error & t Stat \\
\hline Intercept & 1,707 & 0,395 & 4,320 \\
\hline PEOU & 0,254 & 0,105 & 2,226 \\
\hline AISQ & 0,368 & 0,103 & 3,453 \\
\hline
\end{tabular}

Based on the results of data processing, the regression equation values are obtained as follows:

$$
\mathrm{z}=1.707+0.254 \mathrm{X}+0.368 \mathrm{Y}+\varepsilon
$$

This means that if it is in a constant state, the quality of accounting information is affected by 1.707 . The regression coefficient $\mathrm{X}$ of 0.254 states that with every increase in $\mathrm{X}$ (perceived ease of use increases by 1 ), the quality of accounting information increases by 0.254 . The regression coefficient $\mathrm{Y}$ (quality of the accounting information system) is 0.368 indicates that with every increase in $\mathrm{Y}$ (the quality of the accounting information system increases by 1), the quality of accounting information increases by 0.368 .

Table Summary of Results of Respondents' Responses about Ease of Use (Ease of use)

\begin{tabular}{|c|l|c|c|}
\hline No & \multicolumn{1}{|c|}{ Dimension } & Average & Category \\
\hline 1 & clear and understandable & 3,41 & Sufficient \\
\hline 2 & Does not require a lot of mental effort & 3,63 & Sufficient \\
\hline 3 & Easy to Use & 3,73 & Sufficient \\
\hline 4 & Easy to get the system to do what he/she wants to do & 3,38 & Sufficient \\
\hline
\end{tabular}

The Ease of Use variable has 4 (four) dimensions with 7 (seven) indicators show that the average data results of the perceived ease of use of the accounting information system at the research place are in the sufficient category.

Table Summary of Respondents Response Results about the Quality of Accounting Information Systems

\begin{tabular}{|l|l|l|l|}
\hline \multicolumn{1}{|c|}{ No } & \multicolumn{1}{c|}{ Dimension } & \multicolumn{1}{c|}{ Average } & \multicolumn{1}{c|}{ Category } \\
\hline 1 & Flexibilities & 3,89 & Sufficient \\
\hline 2 & Accessibilities & 3,51 & Sufficient \\
\hline 3 & Integration & 3,81 & Sufficient \\
\hline 4 & Formalization & 4,20 & Good \\
\hline
\end{tabular}

The quality variable of the Accounting Information System has 4 (four) dimensions with 8 (seven) indicators show that the average result of the data shows that the quality of the accounting information system at the research place is in the 
sufficient category and formalization dimension average

has a good category.

Table of Summary of Respondents Response Results About the Quality of Accounting Information

\begin{tabular}{|l|l|l|l|}
\hline No & Dimension & Average & \multicolumn{1}{c|}{ Category } \\
\hline 1 & Accurate & 3,87 & Sufficient \\
\hline 2 & Relevant & 3,82 & Sufficient \\
\hline 3 & Verification & 3,89 & Sufficient \\
\hline
\end{tabular}

The variable of the Quality of Accounting Information has 3 (three) dimensions with 5 (five) indicators show on average results of the quality of accounting information data at the research location are in the sufficient category.

\section{DISCUSSION}

1) The Effect of Perceived Ease of Use on Accounting Information System Quality.

The results of this study, indicate that the perceived ease of use affects the accounting information system even though the signification level is low. Perceived ease of use is one of the determining factors in the operational performance of the accounting information system. As expressed by Fred D Davis [24] in his research journal entitled 'Perceived usefulness, Perceived ease of use, and User acceptance of Information Technology' mentioned that usability and ease of use could be affected by various factors that can be controlled externally, such as functional characteristics and system interface.

In the research object, the accounting information system is carried out by each division and unit department. According to the modules contained in the accounting information system, making users not constrained by the characteristics of the system. Company's SOP support control over the flow of transactions that take into account the efficiency and effectiveness of the accounting information system used. Thus, the level of significance of perceived ease of use in influencing the quality of the accounting information system is small, because the perceived ease of use is also influenced by other external factors.

\section{2) The Effect of the Accounting Information System Quality on Accounting Information Quality.}

The results of this study indicate that the effect of the Quality of Accounting Information Systems on the Quality of Accounting Information is quite significant. In the research area, the accounting information system used is quite good even though the ERP is not as sophisticated as SAP. The characteristics of the system are quite complicated with a fairly tight level of security. However, as mentioned above, it is resolved by the company's SOP as an internal control so that the complexity does not become a major obstacle. The company has a good system quality in terms of system reliability, integration, ease of use, and system flexibility which will directly affect quality accounting information.

\section{CONCLUSION}

1) The perception of ease of use in this study shows a significant effect on the quality of the accounting information system even though it is at a low level. This is due to other external factors of the accounting information system in the form of company SOP as a function of internal control. The routine and adaptation of employees to operate the program, make the characteristics of a complex system, not a big obstacle. Because each module unit is done by different but integrated units or employees. This conclusion supports the $\mathrm{H}_{1}$ hypothesis.

2) The company has a good quality accounting information system. Users of accounting reports or information have not been constrained to obtain accounting information at any time accurately and in real-time, so that the resulting strategic decisions can maintain the sustainability and productivity of the company. This conclusion supports the $\mathrm{H}_{2}$ hypothesis.

3) Perceived Ease of Use has an indirect effect on the Quality of Accounting Information. Although the level of significance is low in this study, the contribution of the ease of the system determines the level of accuracy and speed of processing financial data so that the information provided is presented in real-time. This conclusion supports the $\mathrm{H}_{3}$ hypothesis.

\section{SUGGESTION}

1. for the Company

a. To overcome the decline in the quality of accounting information, it is suggested to improve the quality of the accounting information system by periodically evaluating the system, company policies, and internal control as one of the external factors affecting the quality of the accounting information system.

b. The need for a rotation of personnel functions in each department that operates the accounting information system to create a backup system if there are employees who are constrained in carrying out their duties so that company operations can continue as they should and reports can be completed on time.

\section{For Academics}

This study experienced a limited number of samples or small data, which led to the sensitivity of the measurement for Cronbach alpha and resulted in values below the standard reference data validity. Future research is expected to take another perspective from 
the quality of accounting information systems and explore the Technology Acceptance Model (TAM) theory. By adding other variables and by sample or population in different sectors.

\section{REFERENCES}

1. Mamić Sačer, I., Žager, K., \& Tušek, B. (2006). Accounting information system's quality as the ground for quality business reporting. In IADIS International conference, e-commerce 2006 (p. 59).

2. Andesto, R., \& Susanto, A. (2018). The Effect of Organizational Structure on Quality of Management Accounting Information Systems (Survey on Indonesia State-Owned Enterprise). Journal of Engineering and Applied Sciences, 13(8): 2062-2067, 2018.

3. Priyandari, Y., Christian, A. W., Mas'ud, A., \& Teguh, S. Penerapan System Application Product in Data Processing (SAP) pada Modul Material Management-Procurement PT. MAK.

4. Fardinal. (2013). The Quality of Accounting Information and The Accounting Information System through The Internal Control Systems: A Study on Ministry and State Agencies of The Republic of Indonesia. Research Journal of Finance and Accounting, 6.

5. da Silva Nogueira, S. P., \& Jorge, S. M. F. (2017). The perceived usefulness of financial information for decision making in Portuguese municipalities. Journal of Applied Accounting Research.

6. Susanto, A. (2017). How The Quality of Accounting Information System Impact on Accounting Information Quality? (Research on Higher education in Bandung). Journal of Engineering and applied science, 12(14); 36723677.

7. Ajzen, Icek dan Fishbein. (1980). Theory of Reasoned Action, Edisi Kesatu. (Jogiyanto, 2007)

8. Venkatesh., \& Davis. (2000). A Theoretical Extension of the Technology Acceptance Model: Four Longitudinal Field Studies. Management Science, 46(2): 186-204

9. Venkatesh, V., Morris, M. G., Davis, G. B., \& Davis, F. D. (2003). User acceptance of information technology: Toward a unified view. MIS quarterly, 425-478.

10. Venkatesh, V., \& Bala, H. (2008). Technology Acceptance Model 3 and a Research Agenda on Interventions. Decision Sciences, 39(2), 273-315
11. Marshall, B. (2018). Romney dan Paul John Steinbart. Sistem Informasi Akuntansi: Accounting Information Systems (Edisi 14), Prentice-Hall.

12. Burton-Jones, A., \& Hubona, G. S. (2005). Individual differences and usage behavior. $A C M$ SIGMIS Database, 36(2), 58-77.

13. Reynolds, G., \& Stair, R. (2010). Principles of Information Systems: a managerial approach. Cengage Learning.

14. Seddon, P. B. (1997). A respecification and extension of the DeLone and McLean model of IS success. Information systems research, 8(3), 240253.

15. Gelinas, Ulric. Oram, Alan E., Wiggins, William, P. (1990). Accounting Information System. PWSKENT publishing Company. (Memuat informasi mengenai definisi sistem informasi).

16. Heidman, M. (2008). The Role of Management Accounting Systems in Strategic Sensemaking. Belanda: Gabler.

17. Stair, Ralph, M., dan Reynolds, George, W. (2012). "Fundamentals of Information Systems (With Access Code)". USA: Cengage Learning.

18. O'Brien, James. A \& Marakas. George, M. (2010). Management Information Systems: Managing Information Technology in the Bussiness Enterprise. 15th ed. NY: McGraw-Hill. 353, 495

19. Hair, Jr., Joseph, F. (2011). Multivariate Data Analysis. Fifth Edition. New Jersey: PrenticeHall, Inc.

20. McLeod, R. (2007). Sistem Informasi Manajemen. Edisi Ke-7, Versi Bahasa Indonesia, Jakarta: PT. Prenhallindo

21. Hicks. James, O. (1993). Management Information System: A Users Perspectives. Publisher: West Group. Subsequent edition.

22. Maurice, L. Hirsch, Jr., (1994). Advanced Management Accounting, 2nd: South-Western Publishing, 17

23. Hair, J. F., Sarstedt, M., Ringle, C. M., \& Mena, J. A. (2012). An assessment of the use of partial least squares structural equation modeling in marketing research. Journal of the Academy of Marketing Science, 40(3), 414-433.

24. Davis, Fred, D. (1989). Perceived Usefulness, Perceived Ease of Use, and User Acceptance of Information Technology. MIS Quarterly, 13(3), 319-340. 